\title{
Salt intake in young Swedish men
}

\author{
L Hulthén $^{1, *}$, M Aurell ${ }^{2}$, S Klingberg ${ }^{1}$, E Hallenberg ${ }^{1}, M$ Lorentzon ${ }^{3}$ and C Ohlsson ${ }^{3}$ \\ 'Department Clinical Nutrition, Sahlgrenska Academy at University of Gothenburg, Box 459, S-405 30 \\ Gothenburg, Sweden: ${ }^{2}$ Nephrology Department, Sahlgrenska University Hospital, Gothenburg, Sweden: ${ }^{3}$ Center \\ for Bone Research at Sahlgrenska Academy (CBS), Institute of Medicine, University of Gothenburg, Gothenburg, \\ Sweden
}

Submitted 10 December 2008: Accepted 29 July 2009: First published online 8 December 2009

\begin{abstract}
Objective: To measure dietary salt intake in a Swedish population.

Design: A cross-sectional study with measured $24 \mathrm{~h}$ urinary excretion of $\mathrm{Na}$ and $\mathrm{K}$. Completeness of urine collection was assessed using p-aminobenzoic acid. The subjects were interviewed on their habitual food intake.

Setting: Sahlgrenska University Hospital, Gothenburg, Sweden.

Subjects: Eighty-six young men (age 18-20 years), randomly selected from the population of Gothenburg. Seven men were excluded due to incomplete urine collection.

Results: The mean excretion of $\mathrm{Na}$ and $\mathrm{K}$ over $24 \mathrm{~h}$ was 198 and $84 \mathrm{mmol}$, respectively (corresponding to $11.5 \mathrm{~g} \mathrm{NaCl}$ and $3.3 \mathrm{~g} \mathrm{~K}$ ). The mean $24 \mathrm{~h}$ excretion in the highest quartile of $\mathrm{Na}$ excretion was $297 \mathrm{mmol} \mathrm{Na}$ and $105 \mathrm{mmol} \mathrm{K}$, and in the lowest quartile, $100 \mathrm{mmol} \mathrm{Na}$ and $68 \mathrm{mmol} \mathrm{K}$. The mean Na:K ratio was $2 \cdot 3$, and respectively 3.2 and 1.8 in the highest and lowest $\mathrm{Na}$ excretion quartiles. Calculated energy intake did not differ between the highest and lowest quartiles of Na excretion, but body weight, BMI and the intake of certain foods known to be Na-rich did.

Conclusions: Salt intake in young men was alarming high and even subjects in the lowest quartile of $\mathrm{Na}$ excretion did not meet present recommendations to limit salt intake to $5-6 \mathrm{~g} / \mathrm{d}$. At this point we can only speculate what the consequences of the high salt intake may be for CVD and stroke later in life. Regulation of the salt content in processed and fast food and in snacks is advocated, to curtail the salt burden on society imposed by the food industry.
\end{abstract}

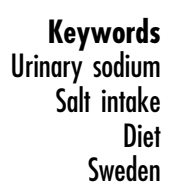

The intake of salt $(\mathrm{NaCl})$ with food is a matter of public health concern worldwide because a high salt intake is associated with hypertension, which is recognized as the leading cause of CVD and stroke ${ }^{(1-4)}$. Health authorities and scientific societies recommend that salt intake should be at most $5-6 \mathrm{~g} / \mathrm{d}(85-102 \mathrm{mmol} \mathrm{Na} / \mathrm{d})$ whether being hypertensive or not ${ }^{(5-8)}$. In Sweden, data based on dietary calculations indicate that the salt intake of middle-aged men and women is substantially greater, but reliable measurements of the actual intake are lacking ${ }^{(9)}$. Moreover, there are very few data on the salt intake in younger age groups. In a rapidly changing society where processed and often salty fast food is served in canteens, worksite restaurants and schools, new and reliable data on salt intake are therefore urgently needed.

We have investigated the salt intake in a group of young men, using the $24 \mathrm{~h}$ urinary excretion of $\mathrm{Na}$ as the measure of salt intake. We also measured the excretion of $\mathrm{K}$ and calculated the total energy intake from the diet and $\mathrm{Na}$ intake from various foods.

\section{Subjects and methods}

\section{Subjects}

The subjects were participants in an epidemiological study of environmental and genetic factors of importance for fat and bone mass, the Gothenburg Obesity and Osteoporosis Determinants (GOOD) study ${ }^{(10,11)}$. Study subjects were randomly identified using national population registers, contacted by telephone, and asked to participate in the study. In total 1068 Caucasian men, mean age 18.9 (SD 0.6) years, from the greater Gothenburg area, were included. To be included in the GOOD study, subjects had to be $>18$ and $<20$ years of age and willing to participate in the study. There were no other exclusion criteria. A standardized questionnaire was used to collect information about current and previous medication, amount of weight-bearing physical activity (hours per week, duration in years), smoking and history of fracture, as well as fracture history in the subjects' families. Data were collected between February 2005 and 
December 2005. The GOOD study was approved by the ethics committee at the University of Gothenburg. Written and oral informed consent was obtained from all study participants.

A subset of eighty-six randomly selected subjects in the GOOD study was investigated for renal $\mathrm{Na}$ and $\mathrm{K}$ excretion and dietary habitual intake. Every tenth subject involved in the study was selected for this sub-sample.

\section{Metbods}

All subjects collected one $24 \mathrm{~h}$ urine sample. The urine samples were collected in acid-washed containers. The start (after the first morning urine) and the end (right after the morning urine the next day) of the urine collection, as well as any lost specimens, were reported. We used the $p$-aminobenzoic acid (PABA) check method to verify that the urine collection was carried out properly. Three $80 \mathrm{mg}$ tablets of PABA were ingested with morning, midday and evening meals for the evaluation of urine collection completeness ${ }^{(12)}$. A collection containing less than $85 \%$ of PABA was excluded, being regarded as incomplete. The volume of the $24 \mathrm{~h}$ collection was determined and a $10 \mathrm{ml}$ aliquot was stored at $-20^{\circ} \mathrm{C}$ until analysis. $\mathrm{Na}$ and $\mathrm{K}$ in urine were determined by flame atomic absorption spectrophotometry (Perkin-Elmer model 5000; Norwalk, CT, USA) according to routine clinical laboratory procedures, and the $\mathrm{Na}: \mathrm{K}$ ratio in the $24 \mathrm{~h}$ urine samples was calculated.

All data on diet evaluation were collected at Sahlgrenska University Hospital. The dietary assessment consisted of a detailed FFQ and an individual interview by a trained nutritionist ${ }^{(11)}$. Each respondent was asked about customary food intake. Portion sizes of foods were described in terms of household measures, standard weights of food items and portion photographs of known weights. This dietary assessment method was previously validated against the doubly labelled water technique and the diet history was found to be valid to assess habitual energy intake ${ }^{(13)}$. Dietary $\mathrm{Na}$ and $\mathrm{K}$ intake was measured as the $24 \mathrm{~h}$ urinary $\mathrm{Na}$ and $\mathrm{K}$ excretion.

Height and weight were measured with subjects in underwear, without shoes, using standardized equipment.
The criterion validation values were below $1 \%$ for these measurements.

Blood pressure was measured in the recumbent position after a $10 \mathrm{~min}$ rest, using the Omron (Santa Clara, CA, USA) $705 \mathrm{CP}$ blood pressure monitor, to the nearest $\mathrm{mmHg}$.

\section{Calculations and statistical analysis}

BMI was calculated from weight (kg) divided by the square of height $\left(\mathrm{m}^{2}\right)$.

Nutrient calculations were performed with the Diet 32 software package (Aivo, Solna, Sweden), which utilizes the Swedish Food Data Base (updated 2001) of the Swedish National Food Administration ${ }^{(14)}$. Snack foods included sweets, nuts, potato crisps, popcorn and cheese doodles. Fast foods included hamburgers, kebab, pizza, hot dogs and chips.

The ratio of energy intake to BMR was used to define under-reporters, acceptable reporters and under-reporters among the participants in the GOOD study ${ }^{(11)}$. The energy intake and food choices of the acceptable reporters are used in the present analysis.

Data are expressed as means and standard deviations. Differences between measurements and groups were analysed with the use of the Mann-Whitney $U$ test. A two-tailed $P$ value of $<0.05$ was considered statistically significant. All statistical analyses were performed with the Statistical Package for the Social Sciences (SPSS for Windows) statistical software package version 11.5 (SPSS Inc., Chicago, IL, USA).

\section{Results}

Seven urine collections were excluded because of insufficient recovery (see Methods). This left seventy-nine collections acceptable for the study. Demographic data on this group of subjects are given in Table 1.

\section{Salt excretion}

The percentage distributions in the $24 \mathrm{~h}$ urinary $\mathrm{Na}$ and $\mathrm{K}$ excretions and the Na:K ratio are given in Fig. 1. There was a considerable variation. $\mathrm{Na}$ excretion varied from

Table 1 Anthropometry and blood pressure in a random sample of seventy-nine young men in Sweden

\begin{tabular}{|c|c|c|c|c|c|c|c|}
\hline & \multicolumn{2}{|c|}{ All subjects ( $n 79)$} & \multicolumn{2}{|c|}{$\begin{array}{l}\text { Highest quartile of } \mathrm{Na} \\
\text { excretion ( } n 20)\end{array}$} & \multicolumn{2}{|c|}{$\begin{array}{l}\text { Lowest quartile of } \mathrm{Na} \\
\text { excretion }(n 20)\end{array}$} & \multirow{2}{*}{$\begin{array}{c}P \text { value } \\
\text { (lowest } v . \text { highest quartile) }\end{array}$} \\
\hline & Mean & SD & Mean & SD & Mean & SD & \\
\hline Age (years) & $18 \cdot 6$ & $0 \cdot 3$ & $18 \cdot 7$ & $0 \cdot 3$ & $18 \cdot 6$ & $0 \cdot 3$ & 0.77 (NS) \\
\hline Height (cm) & $181 \cdot 0$ & $4 \cdot 8$ & $181 \cdot 5$ & $4 \cdot 7$ & $181 \cdot 0$ & 4.9 & 0.83 (NS) \\
\hline Weight (kg) & $74 \cdot 8$ & $9 \cdot 9$ & $79 \cdot 5$ & $14 \cdot 6$ & $69 \cdot 8$ & $10 \cdot 9$ & 0.002 \\
\hline $\operatorname{BMI}\left(\mathrm{kg} / \mathrm{m}^{2}\right)$ & $22 \cdot 5$ & $4 \cdot 8$ & $24 \cdot 1$ & $4 \cdot 2$ & $21 \cdot 1$ & $2 \cdot 8$ & 0.006 \\
\hline $\begin{array}{l}\text { Systolic blood pressure } \\
(\mathrm{mmHg})\end{array}$ & 130 & $9 \cdot 5$ & 131 & 10 & 127 & 9 & $0.53(\mathrm{NS})$ \\
\hline $\begin{array}{l}\text { Diastolic blood } \\
\text { pressure }(\mathrm{mmHg})\end{array}$ & 69 & $3 \cdot 3$ & 70 & 8 & 69 & 8 & 0.80 (NS) \\
\hline
\end{tabular}


(a)

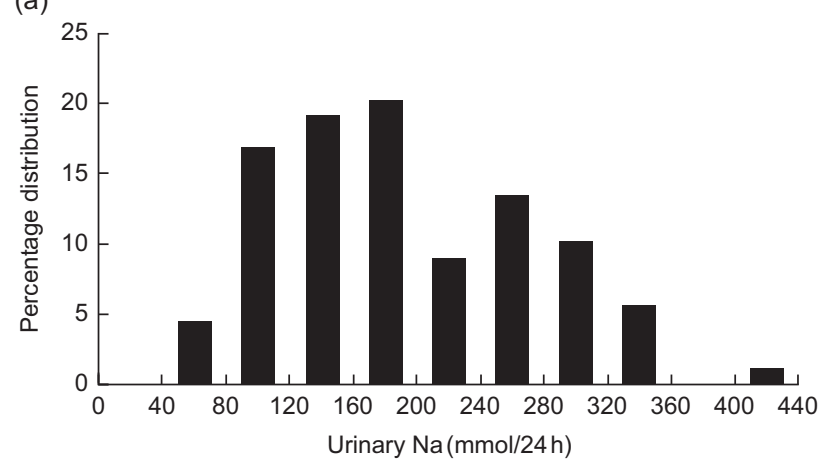

(b)

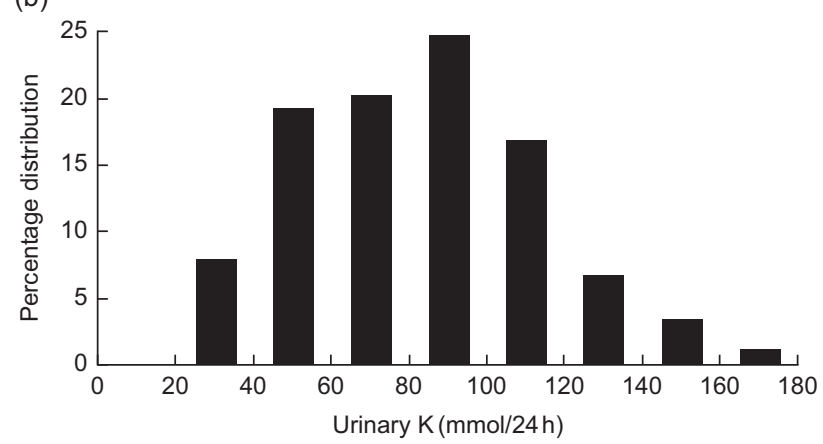

(c)

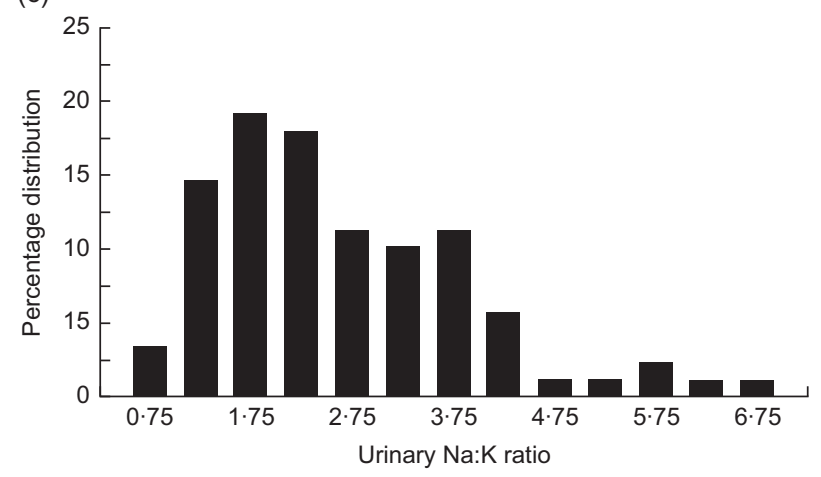

Fig. 1 Distribution of (a) urinary sodium excretion (mmol/24h), urinary potassium excretion ( $\mathrm{mmol} / 24 \mathrm{~h}$ ) and (c) urinary sodium:potassium ratio in young Swedish men $(n 79)$

60 to $420 \mathrm{mmol} / 24 \mathrm{~h}, \mathrm{~K}$ from 30 to $170 \mathrm{mmol} / 24 \mathrm{~h}$ and the $\mathrm{Na}$ K ratio from 0.75 to $6 \cdot 75$.

Mean values for anthropometric and blood pressure measurements were calculated for the whole group and for subjects in the highest and lowest quartiles of $\mathrm{Na}$ excretion. Data in Table 1 show that subjects in the highest quartile were heavier and had higher BMI than subjects in the lowest quartile, but that systolic and diastolic blood pressure did not differ.

Table 2 gives the mean values of salt excretion. Na excretion in the whole group was $198 \mathrm{mmol} / 24 \mathrm{~h}$, which corresponds to $11.5 \mathrm{~g} \mathrm{NaCl}$; in the highest and lowest quartiles, $\mathrm{Na}$ excretion was 297 and $100 \mathrm{mmol} / 24 \mathrm{~h}$, respectively, corresponding to $17 \cdot 2$ and $5 \cdot 8 \mathrm{~g} \mathrm{NaCl}$.
Mean $\mathrm{K}$ excretion was $84 \mathrm{mmol} / 24 \mathrm{~h}$ in the whole group, corresponding to $3 \cdot 3 \mathrm{~g} \mathrm{~K}$; in the highest and lowest $\mathrm{Na}$ excretion quartiles, K excretion was 105 and $68 \mathrm{mmol} /$ $24 \mathrm{~h}$, respectively, corresponding to $4 \cdot 1$ and $2 \cdot 7 \mathrm{~g} \mathrm{~K}$.

Mean $\mathrm{Na}: \mathrm{K}$ ratio was 2.3 in the whole group, and respectively $3 \cdot 2$ and $1 \cdot 8$ in the highest and lowest quartiles of $\mathrm{Na}$ excretion.

\section{Blood pressure}

The young men in the present study were all normotensive; the mean blood pressure is given in Table 1. There was no difference in systolic or diastolic blood pressure between subjects when comparing means across quartiles of $\mathrm{Na}$ excretion. Also, a comparison between the highest and lowest quartiles of $\mathrm{Na}$ and $\mathrm{K}$ excretion and Na:K ratio showed no significant association (data not shown).

\section{Energy intake and diet analysis}

Data on energy intake and some foods are given in Table 3. Energy intake tended to be higher $(P=0 \cdot 07)$ in the highest compared with the lowest quartile of $\mathrm{Na}$ excretion. The intake of fast food and snacks was higher and the intake of fruit and vegetables was lower in the high $\mathrm{Na}$ excretion quartile compared with the low quartile, but none of these differences were statistically significant. The intake of sandwiches, however, was significantly higher in the highest $\mathrm{Na}$ excretion quartile compared with the lowest quartile by no less than $89 \%$.

\section{Discussion}

The present study indicates that the intake of $\mathrm{Na}$ is very high in a representative group of young Swedish men in an urban population. It is in fact double the recommended intake of not more than $80-110 \mathrm{mmol} \mathrm{Na} / \mathrm{d}$ (5-6 g salt/d) issued by WHO in $1982^{(15)}$ and since then adopted in the Nordic Nutrition Recommendations ${ }^{(8)}$ and by all other major international and scientific societies. The $\mathrm{K}$ intake is, however, only slightly below the recommended intake. The resulting Na:K ratio in urine is therefore due to the excessively high $\mathrm{Na}$ intake and indicates a substantial overconsumption of $\mathrm{Na}$ from salt.

Previous data from two small Swedish sub-populations, studies in adolescents, males and females vegans ${ }^{(16)}$ and middle-aged men and women ${ }^{(17)}$, on urinary Na excretion show values corresponding to $8-10 \mathrm{~g}$ salt/d.

The results of the present study also indicate that $\mathrm{Na}$ excretion is positively correlated to body weight and BMI, but almost significantly correlated to energy intake only. This may indicate that subjects with high $\mathrm{Na}$ intake are heavier due to a more sedentary lifestyle and not spending energy on physical activities; the results from the GOOD questionnaire pointed in that direction although the difference was not statistically significant. 
Table 2 Urinary excretion of sodium and potassium in a random sample of seventy-nine young men in Sweden

\begin{tabular}{|c|c|c|c|c|c|c|c|}
\hline & \multicolumn{2}{|c|}{ All subjects $(n 79)$} & \multicolumn{2}{|c|}{$\begin{array}{l}\text { Highest quartile of } \mathrm{Na} \\
\text { excretion }(n 20)\end{array}$} & \multicolumn{2}{|c|}{$\begin{array}{l}\text { Lowest quartile of } \mathrm{Na} \\
\text { excretion }(n \text { 20) }\end{array}$} & \multirow{2}{*}{$\begin{array}{c}P \text { value (lowest } v \text {. highest } \\
\text { quartile) }\end{array}$} \\
\hline & Mean & SD & Mean & SD & Mean & SD & \\
\hline $\mathrm{Na}$ excretion $(\mathrm{mmol} / 24 \mathrm{~h})$ & 198 & 69 & 297 & 40 & 100 & 18 & $<0.001$ \\
\hline Corresponding to $\mathrm{NaCl}(\mathrm{g})$ & $11 \cdot 5$ & $4 \cdot 0$ & $17 \cdot 2$ & $2 \cdot 3$ & $5 \cdot 8$ & $1 \cdot 0$ & $<0.001$ \\
\hline $\mathrm{K}$ excretion $(\mathrm{mmol} / 24 \mathrm{~h})$ & 84 & 27 & 105 & 33 & 68 & 31 & $<0.001$ \\
\hline Corresponding to $\mathrm{K}(\mathrm{g})$ & $3 \cdot 3$ & $1 \cdot 3$ & $4 \cdot 1$ & $1 \cdot 3$ & $2 \cdot 7$ & $1 \cdot 2$ & $<0.001$ \\
\hline Ratio Na:K & $2 \cdot 3$ & $0 \cdot 6$ & $3 \cdot 2$ & $1 \cdot 2$ & $1 \cdot 8$ & $0 \cdot 8$ & $<0.001$ \\
\hline
\end{tabular}

Table 3 Intake of energy and certain foods in a random sample of seventy-nine young men in Sweden with high and low sodium excretion

\begin{tabular}{|c|c|c|c|c|c|c|c|c|}
\hline & \multicolumn{2}{|c|}{ All subjects $(n 79)$} & \multicolumn{2}{|c|}{$\begin{array}{l}\text { Highest quartile of } \mathrm{Na} \\
\text { excretion }(n 13)\end{array}$} & \multicolumn{2}{|c|}{$\begin{array}{l}\text { Lowest quartile of } \mathrm{Na} \\
\text { excretion }(n \text { 12) }\end{array}$} & \multirow{2}{*}{$\begin{array}{l}P \text { value (lowest } v \text {. } \\
\text { highest quartile) }\end{array}$} & \multirow{2}{*}{$\begin{array}{l}\text { Difference (lowest } v \text {. } \\
\text { highest quartile) (\%) }\end{array}$} \\
\hline & Mean & SD & Mean & SD & Mean & SD & & \\
\hline Energy intake (MJ/d) & $14 \cdot 3$ & $4 \cdot 8$ & $15 \cdot 9$ & $3 \cdot 1$ & $13 \cdot 6$ & $3 \cdot 1$ & 0.07 (NS) & +17 \\
\hline Fast food and snacks $(\mathrm{g} / \mathrm{d})$ & 95 & 55 & 104 & 124 & 82 & 44 & 0.57 (NS) & +27 \\
\hline Sandwiches $(g / d)$ & 155 & 55 & 215 & 146 & 114 & 47 & 0.032 & +89 \\
\hline Fruit and vegetables $(\mathrm{g} / \mathrm{d})$ & 155 & 55 & 186 & 134 & 251 & 251 & 0.42 (NS) & -26 \\
\hline
\end{tabular}

These subjects obviously augmented their energy intake with foods known to be salty, which explains the higher $\mathrm{Na}$ intake. The subjects in the low $\mathrm{Na}$ excretion quartile reported fewer snacks, fast foods and sandwiches than the subjects in the high quartile. The young men in the present study have thus made a food selection more neutral to energy than to $\mathrm{Na}$ intake.

Blood pressure is not significantly related to salt excretion in the present study. As high blood pressure is a disease generally starting in the third and fourth decades of life, it may not be surprising that there was no correlation between $\mathrm{Na}$ excretion and blood pressure in this relatively small study in young men. One may, however, speculate what will happen with blood pressure in the next decades if the high $\mathrm{Na}$ intake is maintained, as the kidneys' ability to excrete excess $\mathrm{Na}$ is reduced with age ${ }^{(18,19)}$. It is well known that reducing salt intake reduces blood pressure moderately but significantly in hyper- as well as normotensive middle-aged men and women ${ }^{(1,3,4,20)}$. This fact is underlined in the extensively controlled meta-analysis by He and MacGregor ${ }^{(3)}$, based on twenty-eight carefully selected studies with in total 734 hypertensive and 2220 normotensive individuals. Moderately reduced salt intake has also been shown to substantially reduce cardiovascular morbidity and mortality ${ }^{(4)}$.

The main sources of $\mathrm{Na}$ in the diet are processed foods, e.g. bread, cheese, meat spread and fish products. The contribution of $\mathrm{Na}$ from added salt and salt-containing spice mixtures and condiments varies. In a recent study from Denmark the total salt intake was assessed to be $10 \cdot 6 \mathrm{~g} / \mathrm{d}$ in men and $7 \cdot 1 \mathrm{~g} / \mathrm{d}$ in women ${ }^{(21)}$. The study also suggested that household salt constituted a minor part of the total salt intake, $10 \%$ in men and $9 \%$ in women. The other sources, primarily salt added during processing but also salt added in the preparation of meals in canteens and restaurants, are the most significant sources.

Various ways to reduce salt intake in the population have therefore been advocated. Most of the salt we ingest, in fact $75-80 \%$, derives from processed food such as bread, cheese, meat and fish products, breakfast cereals and fast food. Labelling the salt content in foods has been shown to be a useful tool to reduce Na intake in Finland, by giving consumers the possibility to choose products with less salt ${ }^{(22)}$. Campaigns to change lifestyle factors regrettably often fail to reach out and are often ineffective. Regulation by the authorities of the salt content in various foods is far more effective, as discussed in an important WHO paper ${ }^{(23)}$.

The conclusion is therefore that salt intake in young Swedish men is alarmingly high at present and steps should be taken to reduce it. Regulation of the salt content in processed and fast food and in snacks is advocated to curtail the salt burden on society imposed by the food industry.

\section{Acknowledgements}

Sources of funding: The study was supported by the Swedish Research Council, the Swedish Foundation for Strategic Research, the ALF/LUA Research Grant in Gothenburg, the Lundberg Foundation, the Torsten and Ragnar Söderberg's Foundation, the Petrus and Augusta Hedlund's Foundation, and the Novo Nordisk Foundation. Conflict of interest: The authors have no conflict of interest. Author contributions: M.L. and C.O. were responsible for the design and performance of the GOOD study, M.A and L.H. for the salt part of the study. S.K., E.H. and L.H. were responsible for the dietary assessment. 
S.K. and E.H. administered the dietary assessment. L.H. and M.A. wrote the paper with contributions from the other authors.

\section{References}

1. Stamler J (1997) The INTERSALT study: background, methods, findings, and implications. Am J Clin Nutr 65, 2 Suppl., 626S-642S.

2. Sacks FM, Svetkey LP, Vollmer WM et al.; DASH-Sodium Collaborative Research Group (2001) Effects on blood pressure of reduced dietary sodium and the Dietary Approaches to Stop Hypertension (DASH) diet. New Engl J Med 344, 3-10.

3. He FJ \& MacGregor GA (2002) Effect of modest salt reduction on blood pressure: a meta-analysis of randomized studies. Implication for public health. $J$ Hum Hypertens 16, 761-770.

4. Cook NR, Cutler JA, Obarzanek E, Buring JE, Rexrode KM, Kumanyika SK, Appel LJ \& Whelton PK (2007) Long term effects of dietary sodium reduction on cardiovascular disease outcomes: observational follow-up of the Trials of Hypertension Prevention (TOHP). BMJ 334, 885-888.

5. Fodor JG, Whitmore B, Leenen F \& Larochelle P (1999) Recommendations on dietary salt. CMAJ 160, 9 Suppl., S29-S34.

6. Food Standards Agency (2003) Processed food challenge. Statement on achieving targets in reductions of salt in all processed foods. http://www.food.gov.uk/news/newsarchive/121140 (accessed May 2003).

7. Whelton PK, He J, Appel LJ et al.; National High Blood Pressure Education Program Coordinating Committee (2002) Primary prevention of hypertension. Clinical and public health advisory from the National high blood pressure education program. JAMA 288, 1882-1888.

8. Nordic Council of Ministers (2004) Nordic Nutrition Recommendations 2004. Copenhagen: Nordic Council of Ministers.

9. Becker W \& Pearson M (2002) Riksmaten 1997-98. Metodoch resultatrapport (Dietary Habits and Nutrient Intake in Sweden 1997-98). Uppsala: Swedish National Food Administration.

10. Lorentzon M, Mellström D \& Ohlsson C (2005) Age of attainment of peak bone mass is site specific in Swedish men - The GOOD study. J Bone Miner Res 20, 1223-1227.

11. Klingberg S, Hallenberg E, Lorentzon M, Mellström D, Ohlsson C \& Hulthén L (2008) Characteristics of under- and over-reporters of energy intake among 18-20-year-old males: the Gothenburg Osteoporosis and Obesity Determinants (GOOD) study. Public Health Nutr 11, 1117-1123.

12. Bingham S \& Cummings JH (1983) The use of 4aminobenzoic acid as a marker to validate the completeness of $24 \mathrm{~h}$ urine collections in man. Clin Sci 64, 629-635.

13. Sjöberg A, Slinde F, Arvidsson D, Ellegård L, Gramatkovski E, Hallberg L \& Hulthén L (2003) Energy intake in Swedish adolescents: validation of diet history with doubly labelled water. Eur J Clin Nutr 57, 1643-1652.

14. Swedish National Food Administration (2003) The Food Composition Table - Energy and Nutrients. Uppsala: Swedish National Food Administration.

15. WHO Expert Committee (1982) Prevention of Coronary Heart Disease. WHO Technical Report Series no. 678. Geneva: WHO.

16. Larsson CL \& Johansson GK (2002) Dietary intake and nutritional status of young vegans and omnivores in Sweden. Am J Clin Nutr 76, 100-106.

17. Rosell M, Hellenius ML, de Faire U et al. (2003) Contribution of a manually coded part in an optically readable, precoded seven day food record for the intake of energy, nutrients and foods. Scand J Nutr 47, 123-131.

18. Grim CE, Luft FC, Miller JZ, Brown PL, Gannon MA \& Weinberger MH (1979) Effects of sodium loading and depletion in normotensive first degree relatives of essential hypertensives. J Lab Clin Med 94, 764-771.

19. Gudmundsson $O$, Berglund $G$, Herlitz $H$, Andersson $O$ \& Jonsson J (1983) Influence of age on the response to increased salt intake: effects on blood pressure and sodium in erythrocytes. J Hypertens 1, Suppl. 2, 15-17.

20. Melander O, von Wowern F, Frandsen E, Burri P, Willsteen G, Aurell M \& Hulthén UL (2007) Moderate salt restriction effectively lowers blood pressure and degree of salt sensitivity is related to baseline concentration of rennin and N-terminal atrial natriuretic peptide in plasma. J Hypertens 25, 619-627.

21. Andersen L, Rasmussen LB, Larsen EH \& Jakobsen J (2009) Intake of household salt in a Danish population. Eur J Clin Nutr 63, 598-604.

22. Pietinen P, Valsta LM, Hirvonen T \& Sinkko H (2007) Labelling the salt content in foods: a useful tool in reducing sodium intake in Finland. Public Health Nutr 11, 335-340.

23. Murray CJ, Lauer JA, Hutubessy RC, Niessen L, Tomijima N, Rodgers A, Lawes CM \& Evans DB (2003) Effectiveness and costs of intervention to lower systolic blood pressure and cholesterol: a global and regional analysis on reduction of cardiovascular-disease risk. Lancet 361, 717-725. 